\title{
The acoustic quality and health in urban environments (SALVE) project: Study design, rationale and methodology
}

Timo Haselhoff ${ }^{a \star}$, Bryce Lawrence ${ }^{b}$, Jonas Hornberg ${ }^{a}$, Salman Ahmed ${ }^{\text {a, Robynne Sutcliffe }}{ }^{a}$, Dietwald Gruehn ${ }^{b}$, Susanne Moebus ${ }^{a}$

a Institute for Urban Public Health, University Hospital Essen, University Duisburg-Essen, Essen, Germany

University Hospital Essen | Institute for Urban Public Health | Hufelandstraße 55 | 45147 Essen | Germany

b School of Spatial Planning, Department of Landscape Ecology and Landscape Planning, TU Dortmund University, Dortmund, Germany

TU Dortmund University | School of Spatial Planning, Department of Landscape Ecology and Landscape Planning | August-Schmidt-Straße 10 | 44227 Dortmund | Germany

\section{*Corresponding author}

Timo Haselhoff

timo.haselhoff@uk-essen.de

Hufelandstraße 55 | 45147 Essen | Germany

\section{Co-authors:}

bryce.lawrence@tu-dortmund.de, Jonas.hornberg@uk-essen.de, salman.ahmed@uk-essen.de, Robynne.sutcliffe@uk-essen.de, dietwald.gruehn@tu-dortmund.de, susanne.moebus@uk-essen.de

\section{Keywords}

Urban Acoustic Environment, Soundscape Ecology, study design, public health

\section{Highlights}

- A conceptual sampling framework for measuring the urban acoustic environment is given

- One of the most extensive datasets of the urban acoustic environment is introduced

- Experiences and results of the field work of the SALVE-Project are presented

\section{Abbreviations}

\section{AAP Automated aural procedure}

$\mathrm{AAP}_{24} 24$ stationary devices of the automated aural procedure

$\mathrm{AAP}_{4} \quad$ Four rotation devices of the automated aural procedure

AE Acoustic environment

BP Binaural procedure

NOTE: This preprint reports new research that has not been certified by peer review and should not be used to guide clinical practice.

DAP Direct aural procedure 
medRxiv preprint doi: https://doi.org/10.1101/2021.02.23.21252275; this version posted February 24, 2021. The copyright holder for this preprint (which was not certified by peer review) is the author/funder, who has granted medRxiv a license to display the preprint in It is made available under a CC-BY-NC-ND 4.0 International license .

LU Land use defined by the Regionalverband Ruhr in 2015

\section{Funding}

This work was supported by the Mercator Research Center Ruhr (MERCUR) [PR-2018-006], Essen, Germany.

\section{Abstract}

Sound pressure levels expressed in variations of decibel $(\mathrm{dB})$ formulations are a common approach to describe the urban acoustic environment $(\mathrm{AE})$. In recent years, different approaches gained traction to describe the urban $A E$, like the soundscape ecology approach, which focuses on the natural environment. To determine the feasibility of applying this approach to cities, a comprehensive dataset of high-quality sound recordings with high spatial and temporal resolution is essential.

The acoustic quality and health in urban environments (SALVE) project aims to establish a spatially and temporally high-resolution dataset of the urban AE using land use categories. Since 2019, we assess the $\mathrm{AE}$ at selected places in the densely populated city of Bochum, Germany. For a high temporal resolution, we used automatic devices at 52 locations that recorded every 26 minutes for three minutes. For a high spatial resolution, we used manual devices to perform a five-minute recording four times a year at 730 selected locations. Altogether, we ended up with 1,500,493 minutes of sound recordings.

Aim here is to outline our sampling design, methods used, and applied quality procedures in order to achieve a well-defined and high quality dataset presented for further scientific analysis. To the best of our knowledge, this represents one of the most extensive datasets currently available, which will provide a comprehensive database for future in-depth analyses of the associations between the urban AE, urban fabric and human health. 
medRxiv preprint doi: https://doi.org/10.1101/2021.02.23.21252275; this version posted February 24,2021 . The copyright holder for this preprint (which was not certified by peer review) is the author/funder, who has granted medRxiv a license to display the preprint in

It is made available under a CC-BY-NC-ND 4.0 International license.

\section{Introduction}

The urban acoustic environment $(A E)$ is mainly examined in terms of noise, operationalized as sound pressure level (SPL) and reported mostly as A-weighted equivalent continuous SPL (LAeq), or averaged sound levels ( $L_{d a y}, L_{n}, L_{d n}$ ) [1]. Numerous studies including the comprehensive report of the European Environment Agency have shown the impact of noise on human health [2-11]. However, as the AE can be defined as "the sound from all sound sources modified by the environment" [12], it is likely that SPLs are not sufficient to capture the complexity of the whole AE. For example, Aletta et al. [13] published results of a systematic review assessing associations between positive health-related effects and perceptual soundscape constructs. Their findings suggest that there are more properties of the $A E$ beyond noise that might have an impact on human health.

The soundscape approach allows the analysis of perception-based impacts of the urban AE on human health [14]. However, comprehensive studies demonstrating effects of urban soundscapes on health are still missing. A research field that examines sounds across a variety of different landscapes is the emerging science of soundscape ecology. Through a combination of expertise from spatial and acoustic ecology as well as bio- and psychoacoustics "coupled natural-human dynamics across different spatial and temporal scales" [15] can be described. Here, the use of multiple indices that take frequency and amplitude modulation into account is promoted to describe different properties of the $A E[16]$.

So far, most studies analyzing the urban AE mainly focus on selected areas, like parks, green spaces, recreation areas or specific open spaces [17]. However, as the highly varying properties of the built environment are considered as one of the main influences on (perceived) sounds [14], further data is needed to describe the AE of all types of urban areas, including residential spaces, industrial zones or major and heavily trafficked roads. Previous studies that used spatial stratification, e.g. road type, grid method, land use and examined temporal factors, e.g. length of recording, number of samples, focused exclusively on noise indices [18-21]. Therefore, an essential requirement for the application of the soundscape ecology or perception-based approaches is the availability of comprehensive data in urban environments that considers the high temporal and spatial variability of the urban AE. The acoustic quality and health in urban environments (SALVE) study aims to establish a spatial and temporal highresolution dataset of the urban AE using land use categories. The objective of this paper is to present the study design of SALVE including sampling design, methods used and quality assessment procedures as well as a description of the dataset generated.

\section{Methods}

\subsection{SALVE study design}

SALVE was launched at the end of 2018 as an interdisciplinary study, conducted by the Institute for Urban Public Health at the University Hospital Essen and the Department of Landscape Ecology and Landscape Planning at TU Dortmund University [22]. The main objective of SALVE is to describe the urban $A E$ of the densely populated city of Bochum located in the polycentric metropolitan Ruhr Area, Germany. SALVE aims to establish a quality assured, spatially and temporally high-resolution dataset 
medRxiv preprint doi: https://doi.org/10.1101/2021.02.23.21252275; this version posted February 24,2021 . The copyright holder for this preprint (which was not certified by peer review) is the author/funder, who has granted medRxiv a license to display the preprint in

It is made available under a CC-BY-NC-ND 4.0 International license.

of the urban $\mathrm{AE}$ as a prerequisite to examine the association between the urban $\mathrm{AE}$, the urban fabric and human health.

We pursued both a high spatial resolution to adequately capture the diversity of the built environment as well as a high temporal resolution to understand the daily, weekly, or seasonal variance of the $A E$ [23]. Accordingly, we developed a sampling methodology to investigate the urban AE, considering characteristics of the built environment and available health data.

We applied a random sampling design that is used to apply statistical models to infer the target population. Main prerequisites for this are: (i) the selection probability must be known beforehand, (ii) and the probability of selection for each unit must be $>0$ [24]. To satisfy these conditions, many surveys use sampling frames of the target population. As there is no frame of all possible built environments, we needed a way to approximate this. Additionally, due to limited resources, we needed a way to allocate our $A E$ measuring devices efficiently. In the following, we describe the developed sampling framework, results, and limitations in detail.

\subsection{Sampling Framework}

We defined the target population as the AE of a subset of the urban environment in Bochum. As sounds are influenced by the built environment and this itself is extremely diverse, it must be approximated. We used these approximations as the sampling (or observation) unit. To depict the sound of the entire city, every unit should have a selection probability $>0$ [24].

In SALVE, the urban environment was approximated by the land use (LU) defined by the "Regionalverband Ruhr" in 2015. The LU categorizes all land uses contiguously in the Ruhr Area into their respective designated residential, commercial, industrial, institutional or open space land uses [25]. As we were interested to analyze the association between the $A E$ and health, we limited our target population to the LU categories that contained a residential component ('Wohngebiet'). Also, the LUCategories had to be included in a 600-meter buffer around residences of participants of the Heinz Nixdorf Recall (HNR) health study. The HNR is an ongoing population-based prospective cohort study with participants randomly selected from the lists of the Office of Residence Registration, including the city of Bochum [26]. For the city of Bochum, health data is available for 837 inhabitants. Additionally, we recorded the $A E$ in the two most common forest types and designed public open spaces as a counterpoint. The three largest populations by category of urban green were chosen from the LUCategories of Bochum. The resulting number of distinct areas for each LU-Category is given in table 1 .

The $A E$ was operationalized as physical properties of the $A E$ measured by microphones. We aimed to consider the composition of the whole frequency spectrum to be able to calculate acoustic indices, cross applied from the field of ecoacoustics, that represent characteristics other than noise [16, 27, 28]. Simultaneously, this approach allows the investigation of direct physical effects of urban sounds on humans, independent from their perception. Nevertheless, as human perception is an important process that modulates the effect of the $A E$, we also carried out binaural measurements according to DIN ISO 12913-1:2018-02 [12]. 
medRxiv preprint doi: https://doi.org/10.1101/2021.02.23.21252275; this version posted February 24,2021 . The copyright holder for this preprint (which was not certified by peer review) is the author/funder, who has granted medRxiv a license to display the preprint in

It is made available under a CC-BY-NC-ND 4.0 International license .

We applied three main sampling approaches: (i) a spatially high-resolution sampling approach, using portable sound level meters for manual measurements that follow a direct aural procedure (DAP), (ii) a temporally high-resolution sampling approach, using stationary recording devices that allow an automated aural procedure (AAP) and (iii) a binaural recording procedure (BP) according to the DIN ISO 12913-1:2018-02. The DAP approach allows for an economically reasonable number of devices to achieve a high spatial resolution. However, this approach requires rather high personnel and logistic expense and provides only a temporal snapshot of the AE. The AAP is widely used in ecoacoustics and allows for temporally dense recordings (i.e. high temporal resolution). However, this approach requires numerous devices, which are in jeopardy of being stolen or damaged. The BP allows for subsequent psychoacoustic studies related to our observation units to conform to DIN ISO 12913-2. Details of the respective recording methods are described in chapter 2.3.

With the target population (AE of Bochum), the observation unit (selected LU-Categories) and the measuring procedures defined (DAP, AAP \& BP), the sampling methods can be developed as described in the following.

\subsubsection{Sampling Approach}

We used a stratified sampling approach, as this has several advantages over a simple random sampling: (i) Estimations will be more exact (e.g. avoiding bias), (ii) sampling costs can be reduced and (iii) the strata themselves can be examined [24, 29]. In our case, the strata are based on the LU-Categories presuming that they differ in their $A E$ because of the different properties of their urban and peri-urban environment. Accordingly, the primary sampling unit was the LU-Category, the secondary sampling unit the distinct LU-Area (i.e. the specific parcel in the city).

\subsubsection{DAP Sampling}

The number of desired samples from each stratum was calculated using the formula:

$$
n_{0}=\frac{Z^{2} p q}{e^{2}}
$$

We corrected the results for finite populations, if necessary. Here, $Z$ is defined by the desired $\alpha$-level, $e$ is the margin of error and $p$ the proportion of the population with a given attribute. $q$ equals $1-p$ [30]. To use our resources efficiently, we defined an $\alpha$-level of $5 \%$, a margin of error of $\pm 10 \%$ and assumed maximum variability $(p=0.5)$ for the DAP.

In total, 730 LU-Areas were randomly sampled from their respective LU-Category. We assigned each area a random measurement point, using the ArcGIS add-in from NOAA [31]. Simultaneously, this tool allows the specification of the minimum distance between measurement points, which we set to 500 meters. Each recording point should be sampled four times (once every season). Thus it was estimated that 2920 DAP measurements had to be performed.

\subsubsection{AAP Sampling}

Based on the limitation of 28 available automatic devices, we located three in each of the seven strata of interest plus one in each urban green category. The 24 devices are deployed for 365 days. We will 
medRxiv preprint doi: https://doi.org/10.1101/2021.02.23.21252275; this version posted February 24, 2021. The copyright holder for this preprint (which was not certified by peer review) is the author/funder, who has granted medRxiv a license to display the preprint in

It is made available under a CC-BY-NC-ND 4.0 International license.

refer to these devices in the following as $\mathrm{AAP}_{24}$. Additionally, we used four devices for explorative research interests. These devices are deployed for six weeks each and rotated to another location afterwards. These will be referred to as $\mathrm{AAP}_{4}$. This approach summarizes to $52(24+28)$ sampled LUAreas. The respective measurement points represent a convenient sample. The placement of the automatic devices was done in consultation with the city of Bochum. Using the tree cadaster of the city of Bochum [32], which lists trees on public and private ground, an available tree was selected within the LU-Area of all 52 sample locations.

\subsubsection{BP Sampling}

The binaural recordings for the soundscape approach followed the AAP sampling and the recordings should be made once each season at the $A A_{24}$ and at each new sample location of the $A A D_{4}$.

\begin{tabular}{|c|c|c|c|c|c|c|}
\hline LU-Category $^{1}$ & Bochum $^{2}$ & $600 \mathrm{~m} \mathrm{Buffer}^{3}$ & DAP 4 & AAP $_{24}{ }^{5}$ & $\mathrm{AAP}_{4}{ }^{6}$ & BP $^{7}$ \\
\hline Residential areas, up to 3 floors & 4,245 & 4,155 & 94 & 3 & 3 & 6 \\
\hline Residential areas, up to 5 floors & 2,824 & 2,807 & 93 & 3 & 3 & 6 \\
\hline Residential areas, over 5 floors & 202 & 202 & 66 & 3 & 4 & 7 \\
\hline Commercial mixed Use & 1,018 & 1,005 & 88 & 3 & 3 & 6 \\
\hline Mixed industrial / residential areas & 1,273 & 1,169 & 90 & 3 & 4 & 7 \\
\hline Public and institutional facilities & 239 & 234 & 69 & 3 & 4 & 7 \\
\hline Agricultural land with homesteads & 131 & 107 & 56 & 3 & 4 & 7 \\
\hline Designed neighborhood parks & 1,402 & 1,390 & 90 & 1 & 3 & 4 \\
\hline Deciduous forest & 133 & 117 & 57 & 1 & 0 & 1 \\
\hline Mixed forest & 36 & 35 & 27 & 1 & 0 & 1 \\
\hline Total: & 11,503 & 11,221 & 730 & 24 & 28 & 52 \\
\hline
\end{tabular}

Table 1: Number of LU-Categories in Bochum and sampled LU-Areas for each procedure

${ }^{1}$ LU-Category of the "Regionalverband Ruhr", own translation; ${ }^{2}$ number of LU-Areas in Bochum; ${ }^{3}$ number of LUAreas in a $600 \mathrm{~m}$ Buffer around the HNR participants; ${ }^{4}$ number of sampled LU-Areas from the respective LUCategory for the DAP; ${ }^{5}$ number of sampled LU-Areas from the respective LU-Category for the AAP 24 ; ${ }^{6}$ number of sampled LU-Areas from the respective LU-Category for the $\mathrm{AAP}_{4} ;{ }^{7}$ number of sampled LU-Areas from the respective LU-Category for the BP.

\subsection{Measurement Procedures}

\subsubsection{DAP Recordings}

To organize the DAP sound recordings effectively, clustering of the 730 DAP sample points was performed in ArcGIS (10.5) with Grouping Analysis (K_Nearest Neighbors) to build 35 DAP point cluster. In order to optimize the travel times, we built a network dataset in ArcGIS from multilevel roadways then used the New Route function to created optimized routes for each cluster. This allowed the field staff to record five minutes at all points of one cluster in one day, assuming five minutes to prepare the device and an average walking speed of five $\mathrm{km} / \mathrm{h}$. As a result, 140 field days were necessary to measure all 730 sampled areas four times. The field days were distributed evenly over working days for 52 weeks. Days of the week on which measurements were to be taken were randomized to prevent selection bias. All measurements were scheduled between 9 a.m. and 5 p.m. As not all pre-defined sampling points were accessible (e.g. because of points "on" buildings, private places, construction work etc.), the field staff was advised to measure as near as possible to the pre-defined sampled points. If the new sampling point deviated by more than five meters from the pre-defined point and/or changed to an adjacent LU- 
medRxiv preprint doi: https://doi.org/10.1101/2021.02.23.21252275; this version posted February 24,2021 . The copyright holder for this preprint (which was not certified by peer review) is the author/funder, who has granted medRxiv a license to display the preprint in

It is made available under a CC-BY-NC-ND 4.0 International license .

Area, the new sampling point was documented in the field map and later updated in ArcGis. Thus, it was ensured that the follow-up measurements could be performed at the same place.

The DAP recording was done by mounting the microphone on a stand at around $1.65 \mathrm{~m}$ height, reflecting the approximated average height of a human ear [12]. The five-minute audio recording was carried out, using the NTi XL2 sound recording device with the M2230 omni-directional microphone [33]. When coupled with the MA 2230 microphone/preamp, the XL2 device was calibrated to meet the following IEC standards: IEC 61672:2013, IEC 61672:2003, IEC 61260:2014, IEC 61260:2003, IEC 60651, IEC 60804. The mono-recording was sampled at $48,000 \mathrm{~Hz}$ and with 24-bit depth. All files were stored in the WAVE format. Concurrently with each DAP measurement; weather-data was recorded in order to consider weather effects. Temperature, wind speed, humidity and atmospheric pressure were measured using the Skywatch Windoo 3 [34]. As we experienced that the Windoo device did not work all the time properly, the field staff was advised to use data from weather.com as a proxy and to document this in the field report. The fieldwork was paused or postponed in case of heavy rain to avoid biasing sounds and damage to the microphones.

\subsubsection{AAP Recordings}

Upon each tree chosen from the tree cadaster, a Wildlife Acoustics SM4 Acoustic Recorder with a SMMA2 microphone was mounted [35] at a height of approx. $1.65 \mathrm{~m}$. The devices were configured to carry out a 3-minute measurement every 26 minutes, so we end up with a minimum of two recordings per hour of day. The mono-recordings were sampled at $44,100 \mathrm{~Hz}$ with a bit-depth of 16 . The data was also stored as WAVE.

The $\mathrm{AAP}_{24}$ were set to record for 365 days straight and each of the $\mathrm{AAP}_{4}$ for six weeks, eight times the year. The devices needed battery and memory card replacements every six to eight weeks, resulting in eight maintenance days for $\mathrm{AAP}_{24}$ for one year. The same maintenance frequency applied to the $\mathrm{AAP}_{4}$. For all AAP, no weather data was recorded directly at the device.

\subsubsection{Binaural Recordings}

Binaural recordings were planned once each season at the $A A D_{24}$ and at each new sample location of the $A A D_{4}$, resulting in an estimated number of $124(24 \cdot 4+28)$ recordings. For the binaural recordings, a 3Dio FS Pro II [36] with a ZOOM H4nPro stereo recording device [37] was used. The stereo-recordings had a length of five minutes, a sampling rate of $44,100 \mathrm{~Hz}$ and a bit depth of 24 . Additionally, a 170 degree panorama picture was created for each recording location.

In total, $2920 \mathrm{DAP}_{-}, 438000 \mathrm{AAP}_{24^{-}}, 58800 \mathrm{AAP}_{4^{-}}$and 124 binaural-recordings were estimated by the developed sampling framework.

\section{Results}

DAP measurements were carried out from 18.03.2019 to 19.03.2020. AAP 24 measurements since 06.05.2019 and $\mathrm{AAP}_{4}$ measurements since 01.08.2019. In total the recorded sound data of the SALVE project reaches $1,500,493$ minutes, or 1042 days of continuous recording respectively. $1 \%$ of them 
medRxiv preprint doi: https://doi.org/10.1101/2021.02.23.21252275; this version posted February 24,2021 . The copyright holder for this preprint (which was not certified by peer review) is the author/funder, who has granted medRxiv a license to display the preprint in It is made available under a CC-BY-NC-ND 4.0 International license .

were recorded using the $\mathrm{DAP}, 83 \%$ using the $\mathrm{AAP}_{24}, 16 \%$ using the $\mathrm{AAP}_{4}$ and $0,04 \%$ using the binaural procedure (table 2).

\begin{tabular}{cccc}
\hline Method & Recordings $(\mathbf{n})$ & Length of recording & Total length \\
\hline DAP & 2,433 & $5 \mathrm{~min}$ & $12,165 \mathrm{~min}$ \\
$\mathrm{AAP}_{24}$ & 416,797 & $3 \mathrm{~min}$ & $1,250,391 \mathrm{~min}$ \\
$\mathrm{AAP}_{4}$ & 79,114 & $3 \mathrm{~min}$ & $237,342 \mathrm{~min}$ \\
$\mathrm{BP}$ & 119 & $5 \mathrm{~min}$ & $595 \mathrm{~min}$ \\
\hline Total & 498,463 & & $1,500,493 \mathrm{~min}$ \\
\hline
\end{tabular}

In total the dataset has a size of 7.44 Terabyte $(D A P=100 \mathrm{~GB} ; A A P 24=6.16 \mathrm{~TB}, \mathrm{AAP} 4=1.17 \mathrm{~TB}, \mathrm{BP}=5.4 \mathrm{~GB})$

The final dataset contains fewer measurements than estimated above due to common field measurement disruptions, such as inclement weather conditions, technical equipment failures, and personnel error. Problems of the DAP were mainly caused by an initially wrong factory calibration of one microphone and cable shorts. As the field collection started in early spring, most of the disruptions occurred in this time (Appendix A.1). Initially not considered LU-Categories have been included due to deviations from the pre-defined measurement points (mean $=17.2 \mathrm{~m}$ ). Reasons were mainly that predefined locations were placed on private property, commercial or industrial locations. Further reasons for changing or excluding pre-definded measurement points included pedestrians talking directly into the microphone, measurements outside the desired timespan or individual mistakes in locating the device. Regarding the weather data, all Windoo devices had several malfunctions, resulting in missing full weather data for $14 \%(n=347)$ of the recordings. By means of various organizational and logistical modifications the DAP measurements are not evenly distributed over the working days (Appendix A.2). Most measurements were deployed in the given time-span from 9 a.m. to 5 p.m. with only 72 recordings outside the planned interval. The frequencies of the recordings by daytimes are depicted in Appendix A.3. The distribution with peaks at 11 and 12 a.m. and lowest number at 9 a.m. and 4 p.m. are justified by the given routes per cluster.

The $\mathrm{AAP}_{24}$ devices were deployed on 06.05.2019. One device was unknowingly damaged shortly after deployment, which we only noticed well into the measurement period so that a replacement was no longer reasonable. Hence, only 23 devices covering the same recording period are available for data analysis. Other reasons for recording dropouts have occurred for the following reasons: one device could not be put into operation for six weeks, two devices ran into battery problems and one device was destroyed with an axe and replaced after a two month gap. For an overview of all recording periods, see Appendix B.3. The $\mathrm{AAP}_{4}$ devices were first deployed on 01.08.2019 changing locations six times until 06.07.2020. One issue with the locks we used to mount the devices resulted in leaving the devices in the same place for an additional six weeks. Thus, the overall number of measurement exceeds the estimated one with 79,114 files recorded. Given the limitation of using trees as AAP device mounting location we had mount AAP devices a small distance away from the target LU-Area in some cases. The target and the actual measured LU-Category for all AAPs can be found in Appendix B.

The BP was mostly carried out as planned, however, we measured twice in the spring for the $A_{A} D_{24}$ and thus skipped the summer recordings. Therefore, we ended up with the estimated number of recordings, 
medRxiv preprint doi: $h$ ttps://doi.org/10.1101/2021.02.23.21252275; this version posted February 24, 2021. The copyright holder for this preprint (which was not certified by peer review) is the author/funder, who has granted medRxiv a license to display the preprint in

It is made available under a CC-BY-NC-ND 4.0 International license .

but with different periods measured. The recordings at the $\mathrm{AAD}_{4}$ went mostly as planned, but five recordings were missed out due to reasons describe above (Appendix B.2).

The sound measurements were mostly received positively by the citizens. One reason might have been, that information flyers were placed in every mailbox surrounding the devices location and a sticker for further information was put on each device. Nevertheless, two AAP devices had to be moved by about 300 meters due to resident complaint. Also, the police was called by suspicious residents three times during DAP field days. However, the team member informed the police and every time the police officers saw no issues with the project, so that the measurements could be continued.

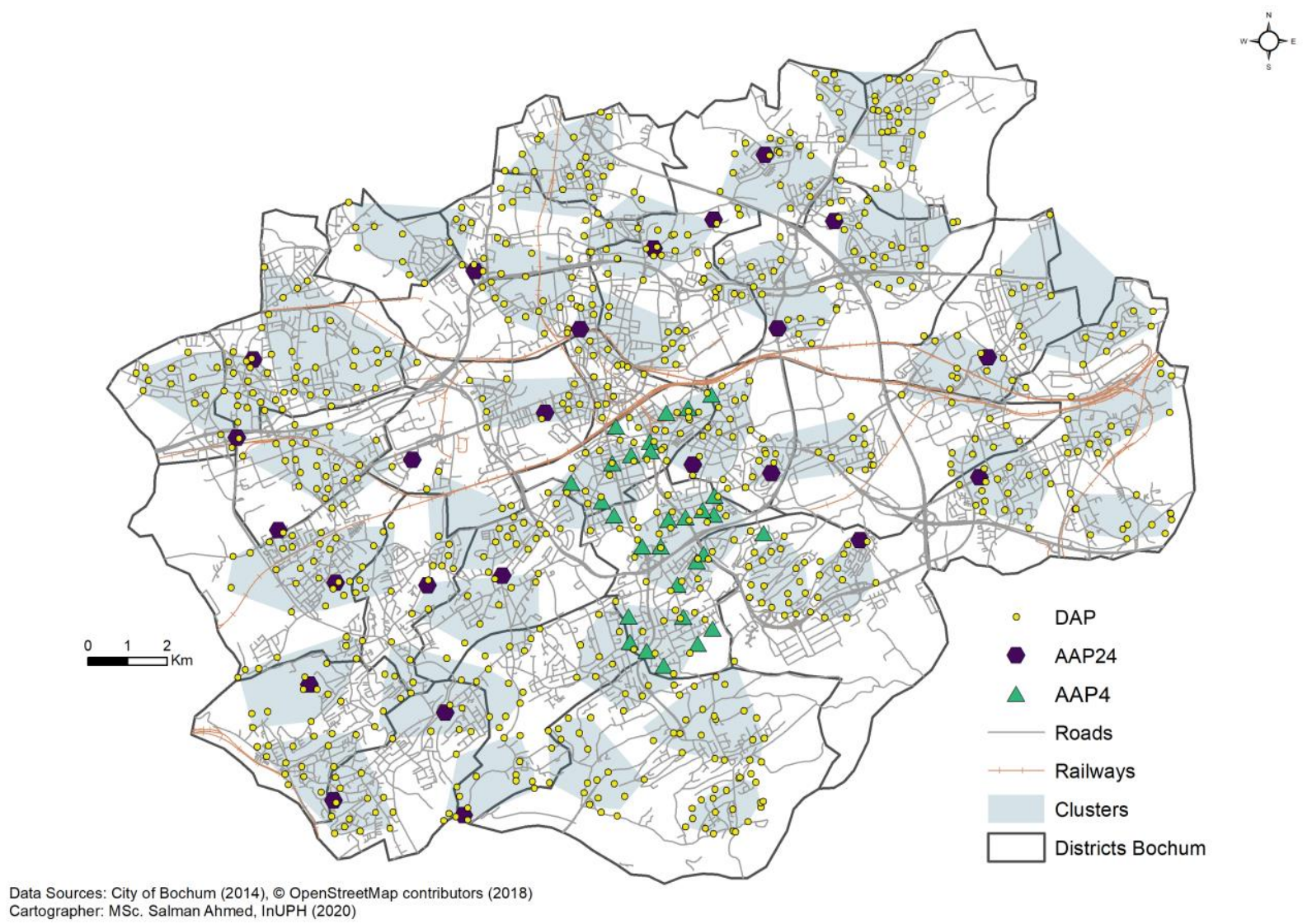

Figure 1: Measured points by recording procedure in Bochum, Germany

\subsection{Quality assurance}

To ensure the quality of the measurements, we implemented an accompanying quality assurance. Prior to the fieldwork, main study elements, like implementation, application, and evaluation of the study were documented in a detailed and binding study protocol. Rules for and comments on the conduct of the data collection were fixed in a written form and made available to the field team. Changes during the field phase were documented as amendments. The study personnel involved in the field study were skilled and trained prior to the beginning of the fieldwork. The training comprised a theoretical introduction to the study objective, training the use of devices and field procedures, followed by one field day with an experienced guide. Monthly team meetings ensured a regular exchange of experiences and an adjustment of methods, if necessary. Calibrations for all devices were checked beforehand and their 
medRxiv preprint doi: https://doi.org/10.1101/2021.02.23.21252275; this version posted February 24,2021 . The copyright holder for this preprint (which was not certified by peer review) is the author/funder, who has granted medRxiv a license to display the preprint in

It is made available under a CC-BY-NC-ND 4.0 International license.

settings were streamlined. The collected data was comprehensively checked for plausibility, using descriptive statistics on all measured variables. Large deviations or potentially implausible data were discussed between all team members and results were documented accordingly. Necessary changes were saved in a new dataset.

\section{Discussion}

In SALVE, a methodology was developed and applied to assess the urban AE in the City of Bochum, taking into account the built environment. The resultant dataset is proof of concept of the sampling and data collection procedure and created a dataset to further understand the urban AE. The measurement techniques for each procedure were outlined as well as their applications in the field. Many of these were similar to the applications in ecoacoustics, but additional complications, mostly regarding fieldwork in the urban environment, had to be solved. The suggested methods can be easily adapted in surveys of the AE in other cities. Nevertheless, future analysis of the recorded sound data of SALVE must prove if the framework is appropriate for representing the $A E$ in dependence to the built environment.

Altogether, the data of the SALVE project represents a disproportionally stratified random sample of LUAreas in a 600-meter buffer around participants of the HNR for the DAP and a convenient sample with a temporal resolution of approx. two three minute recordings per hour for each device over one year for the AAP. In addition, the BP generated 119 binaural recordings over one year.

Although the DAP provided a high spatial resolution, there were difficulties in the field, resulting in a possibly biased dataset, if sounds differ systematically by working day and/or daytime. Still the DAP data provides the possibility to investigate the $A E$ in a high spatial resolution. The AAP on the other hand had fewer issues: the resulting recordings allow for detailed analysis with a high temporal but low spatial resolution. The binaural recordings and their respective panorama pictures allow for analysis using the perceptual soundscape approach. All data will be made available for scientific research.

\subsection{Strengths and limitations}

One of the strengths of SALVE is the systematic approach to capture the AE of a wide range of types of urban areas taking into account possible temporal variances. A further strength is the implementation of a rigorous quality management procedure, including the application of a study protocol, qualification and training of the field staff, plausibility checks of assessed sound recordings and all measured variables. Furthermore, linking the sound data to results of a population-based health study will likely bring new insights of effects of the urban AE on humans. For the future, the recorded sound data will allow a great variety of analysis. Due to the length, the sampling frequency, and the uncompromised file-format of the sound data, a wide range of sound information is available. Especially the high spatial and temporal resolution enables detailed investigations of the properties of the $A E$ that opens up the possibilities e.g. of using machine learning approaches. As neither the DAP nor the AAP focusses solely on one dimension, inter and intra comparisons of the temporal and spatial structure of urban sounds are possible.

Some limitations of the study deserve special mention. The sampling design aims at recording the $A E$ of Bochum as efficiently as possible. However, LU-Categories were restricted to the residentially related 
medRxiv preprint doi: https://doi.org/10.1101/2021.02.23.21252275; this version posted February $24,2021$. The copyright holder for this
preprint (which was not certified by peer review) is the author/funder, who has granted medRxiv a license to display the preprint in It is made available under a CC-BY-NC-ND 4.0 International license .

land uses within a 600-meter buffer of the participants of the HNR study. Therefore, not all LUCategories were taken into account. Although the HNR is a simple random sample of the population between 45 and 75 years [26] and our DAP sample therefore still is a random sample of a random sample (ignoring panel-effects), it is not a random sample of the urban environment of Bochum anymore. Secondly, regarding the DAP not all working days were sampled equally which leads to an oversampling on Wednesdays and Thursdays and undersampling of Mondays and Fridays. However, since we also have $A A D$ recordings available with records during the whole week, the magnitude of this oversampling can likely be determined. Next steps are to check if the LU is an appropriate approximation for the built environment to describe the pattern of the urban AE. For instance, if the AE inside the same LUCategory is not more similar than the ones between the different LU-Categories, a stratification by LU can be hardly justified for future studies. The same is true for temporal differences.

\section{Conclusion}

With SALVE we achieved a longitudinal set of recordings systematically gathered from the urban environment with both automated and manual procedures, which is so far one of the largest AE datasets ever recorded. This dataset can be used for a wide array of upcoming studies. The innovative element of this study is that it couples the field of epidemiology with the field of ecoacoustics and urban planning, thereby treating urban land use as so called "human habitat patches" and seeks to use sound as an indicator for habitat quality - similar to the use of sound in ecoacoustics as measures of non-human animal habitat quality. Our aim is to characterize the urban environment taking into account the extent of differences and similarities between recordings of the $A E$ within different urban land use types. This approach will lead to an understanding of the nature and complexity of sounds in the human dominated urban fabric.

Overall, we aim to address questions especially regarding associations between the built environment and the $\mathrm{AE}$, associations between human health and the $\mathrm{AE}$, connection of physical sound measurements and human perception and a methodology for appropriate sound sampling to represent the sounds of the urban environment. 
medRxiv preprint doi: https://doi.org/10.1101/2021.02.23.21252275; this version posted February 24, 2021. The copyright holder for this preprint (which was not certified by peer review) is the author/funder, who has granted medRxiv a license to display the preprint in

It is made available under a CC-BY-NC-ND 4.0 International license .

\section{Literature}

1. Directive, E., Directive 2002/49/EC of the European parliament and the Council of 25 June 2002 relating to the assessment and management of environmental noise. Official Journal of the European Communities, 2002. 189(18.07): p. 2002.

2. Babisch, W., B. Beule, M. Schust, N. Kersten, and H. Ising, Traffic noise and risk of myocardial infarction. Epidemiology, 2005. 16(1): p. 33-40.

3. Barregard, L., E. Bonde, and E. Ohrstrom, Risk of hypertension from exposure to road traffic noise in a population-based sample. Occup Environ Med, 2009. 66(6): p. 410-5.

4. Chang, T.Y., B.F. Hwang, C.S. Liu, R.Y. Chen, V.S. Wang, B.Y. Bao, and J.S. Lai, Occupational noise exposure and incident hypertension in men: a prospective cohort study. Am J Epidemiol, 2013. 177(8): p. 818-25.

5. Fuks, K., S. Moebus, S. Hertel, A. Viehmann, M. Nonnemacher, N. Dragano, S. Mohlenkamp, H. Jakobs, C. Kessler, R. Erbel, B. Hoffmann, and G. Heinz Nixdorf Recall Study Investigative, Longterm urban particulate air pollution, traffic noise, and arterial blood pressure. Environ Health Perspect, 2011. 119(12): p. 1706-11.

6. Kälsch, H., F. Hennig, S. Moebus, S. Möhlenkamp, N. Dragano, H. Jakobs, M. Memmesheimer, R. Erbel, K.-H. Jöckel, and B. Hoffmann, Are air pollution and traffic noise independently associated with atherosclerosis: the Heinz Nixdorf Recall Study. European Heart Journal, 2014. 35(13): p. 853-860.

7. Orban, E., K. McDonald, R. Sutcliffe, B. Hoffmann, K.B. Fuks, N. Dragano, A. Viehmann, R. Erbel, K.-H. Jöckel, and N. Pundt, Residential road traffic noise and high depressive symptoms after five years of follow-up: results from the Heinz Nixdorf recall study. Environmental Health Perspectives, 2016. 124(5): p. 578-585.

8. Peris, E., N. Blanes, J. Fons, M.S.d.I. Maza, M.J. Ramos, F. Domingues, K. Biala, M. Peterlin, C. Ganzleben, and M. Adams, Environmental noise in Europe - 2020. 2019, EEA: Luxembourg.

9. Selander, J., M.E. Nilsson, G. Bluhm, M. Rosenlund, M. Lindqvist, G. Nise, and G. Pershagen, Long-term exposure to road traffic noise and myocardial infarction. Epidemiology, 2009. 20(2): p. 272-9.

10. Sørensen, M., Z.J. Andersen, R.B. Nordsborg, T. Becker, A. Tjønneland, K. Overvad, and O.J.E.h.p. Raaschou-Nielsen, Long-term exposure to road traffic noise and incident diabetes: a cohort study. Environmental Health Perspectives, 2013. 121(2): p. 217-222.

11. Sørensen, M., M. Hvidberg, Z.J. Andersen, R.B. Nordsborg, K.G. Lillelund, J. Jakobsen, A. Tjønneland, K. Overvad, and O. Raaschou-Nielsen, Road traffic noise and stroke: a prospective cohort study. European Heart Journal, 2011. 32(6): p. 737-744.

12. DIN ISO 12913-1:2018-02, Acoustics - Soundscape - Part 1: Definition and conceptual framework (ISO 12913-1:2014).

13. Aletta, F., T. Oberman, and J. Kang, Associations between positive health-related effects and soundscapes perceptual constructs: A systematic review. Int. J. Environ. Res. Public Health, 2018. 15(11): p. 2392.

14. Kang, J. and B. Schulte-Fortkamp, Soundscape and the built environment. 2016: CRC press Boca Raton, FL, USA:.

15. Pijanowski, B.C., A. Farina, S.H. Gage, S.L. Dumyahn, and B.L. Krause, What is soundscape ecology? An introduction and overview of an emerging new science. Landscape Ecology, 2011. 26(9): p. 1213-1232.

16. Sueur, J., Sound analysis and synthesis with R. 2018, Culemborg, Netherlands: Springer.

17. van Kempen, E., J. Devilee, W. Swart, and I. van Kamp, Characterizing urban areas with good sound quality: development of a research protocol. Noise Health, 2014. 16(73): p. 380-7.

18. Bąkowski, A., L. Radziszewski, and Z.J.P.E. Skrobacki, Assessment of uncertainty in urban traffic noise measurements. Procedia Engineering, 2017. 177: p. 281-288.

19. Fiebig, A. Reliability of in-situ measurements of acoustic environments. in Proc. DAGA. 2016.

20. Jagniatinskis, A., B. Fiks, and O. Zaporozhets, Annual assessment of transport noise using representative time measurements. Procedia Engineering, 2016. 134: p. 301-308. 
medRxiv preprint doi: https://doi.org/10.1101/2021.02.23.21252275; this version posted February 24, 2021. The copyright holder for this preprint (which was not certified by peer review) is the author/funder, who has granted medRxiv a license to display the preprint in

It is made available under a CC-BY-NC-ND 4.0 International license.

21. Liguori, C., A. Ruggiero, D. Russo, and P. Sommella, Estimation of the minimum measurement time interval in acoustic noise. Applied Acoustics, 2017. 127: p. 126-132.

22. Sutcliffe, R., B.T. Lawrence, S. Ahmed, D. Gruehn, and S. Moebus, Acoustic quality and health in urban environments (SALVE) - a pilot study in the metropolitan Ruhr region, Germany. Cities \& Health, 2020: p. 1-7.

23. Guarnaccia, C., J. Quartieri, and C. Tepedino. Validation of Seasonal ARIMA Models on Road Traffic Noise Measurements. in MATEC Web of Conferences. 2018. EDP Sciences.

24. Kalton, G., Introduction to survey sampling. Vol. 35. 1983, Newbury Park: SAGE.

25. Regionalverband Ruhr. Flächennutzungskartierung. Daten für die Stadt- und Regionalplanung. 2020; Available from: https://www.rvr.ruhr/datendigitales/geodaten/flaechennutzungskartierung/ [accessed 10 December 2020].

26. Erbel, R., L. Eisele, S. Moebus, N. Dragano, S. Möhlenkamp, M. Bauer, H. Kälsch, and K.-H. Jöckel, Die Heinz Nixdorf Recall Studie. Bundesgesundheitsblatt-GesundheitsforschungGesundheitsschutz, 2012. 55(6-7): p. 809-815.

27. Sueur, J. and A. Farina, Ecoacoustics: the ecological investigation and interpretation of environmental sound. Biosemiotics, 2015. 8(3): p. 493-502.

28. Bradfer-Lawrence, T., N. Gardner, L. Bunnefeld, N. Bunnefeld, S.G. Willis, and D.H. Dent, Guidelines for the use of acoustic indices in environmental research. Methods in Ecology and Evolution, 2019. 10(10): p. 1796-1807.

29. Schnell, R., Survey-Interviews. Methoden standardisierter Befragungen. 2012, Wiesbaden: VS Verlag.

30. Israel, G.D., Determining sample size. 1992, Gainesville, FL: University of Florida.

31. NOAA. NOAA's GeoPlatform. 2020; Available from: https://noaa.maps.arcgis.com/home/index.html [accessed 10 December 2020].

32. Regionalverband Ruhr. Baumkataster Stadt Bochum. 2017; Available from: https://daten.geoportal.ruhr/srv/api/records/44ebb2f0-0208-402f-84f0-8b0a41eb7d01 [accessed 10 December 2020].

33. NTi Audio. Technische Daten Messmikrofone. 2020; Available from: https://www.ntiaudio.com/Portals/0/data/de/Messmikrofone-Spezifikationen.pdf [accessed 10 December 2020].

34. Windoo. Global specifications. 2020; Available from: http://windoo.ch/index.php/specifications [accessed 10 December 2020].

35. Acoustics, W. Song Meter SM4 Acoustic Recorder. 2020; Available from: https://www.wildlifeacoustics.com/products/song-meter-sm4 [accessed 10 December 2020].

36. 3DIO. Free Space Pro II Binaural Microphone. 2020; Available from: https://3diosound.com/products/free-space-pro-binaural-microphone [accessed 10 December 2020].

37. Zoom. H4nPro Handy Recorder Operation Manual. 2020; Available from: https://www.zoomna.com/sites/default/files/products/downloads/pdfs/E H4n Pro 0.pdf $\frac{\text { [accessed } 10}{10}$ December 2020]. 